\title{
PERNIKAHAN DINI PERSPEKTIF MAHASISWA IAI MUHAMMADIYAH BIMA
}

\author{
Yayuk Kusumawati \\ Institut Agama Islam (IAI) Muhammadiyah Bima \\ Jln. Anggrek No. 16 Ranggo Na'e Kota Bima \\ yayukalkhansa@gmail.com
}

\section{Abstrak}

Tulisan ini bertujuan untuk mengetahui perpektif dan respon mahasiswa tentang pernikahan dini yang terjadi di lingkungan kota Bima. Pernikahan dini terjadi disebabkan karena faktor marak terjadinya hubungan suami istri tanpa melalui ikatan pernikahan. Hal ini juga, akan berakibat kerap terjadinya kekerasan rumah tangga dan percaraian disebabkan usia pernikahan yang masih sangat labil. Adapun metodologi penelitian yang digunakan oleh penulisan dalam topik ini adalah studi kasus yang terjadi di kota bima dengan menggunakan data primer dan skunder, analisis data dalam penelitian ini menggunakan analisis deskriptik kualitatif. Hasil penelitian ini menunjukan bahwa secara keseluruhan mahasiswa tidak sepakat dengan adanya pernikahan dini, sebab dapat memperhambat proses pendidikan secara formal, dan penilaian masyarakat secara negatif.

Keywords: Pernikahan Dini, Mahasiswa. 


\section{PENDAHULUAN}

\section{Latar Belakang}

Menurut Undang-Undang perkawinan No.1 Tahun 1974 pada pasal 7 ayat (1) yang menyatakan bahwa pasangan calon pengantin pria dapat melangsungkan perkawinan apabila telah berusia 19 tahun dan calon pengantin wanita telah berusia 16 tahun dengan ketentuan harus ada ijin dari orang tua. Namun jika terjadi hal yang menyimpang dari Undang-Undang tersebut misalnya karena adanya pergaulan bebas seorang wanita hamil di luar pernikahan dan wanita tersebut belum mencapai umur 16 tahun dan pria belum mencapai umur 19 tahun maka UndangUndang No. 1 Tahun 1974 masih dapat memberikan kemungkinan dari batas umur yang telah di tetapkan yaitu dengan meminta dispensasi kepada pengadilan atau pejabat lain yang di tunjuk oleh kedua orang tua dari pihak wanita maupun pihak pria, hal ini berdasar pada pasal 7 ayat 2 Undang-Undang Perkawinan No. 1 Tahun 1974. Tetapi jika melihat dari sudut pandang ilmu kesehatan baik secara kesempurnaan dan psikologi, umur yang ideal untuk menikah, bagi laki-laki 25 tahun dan perempuan 20 tahun ${ }^{1}$.Tetapi masih banyak yang tidak memperdulikan hal tersebut, bukan hanya di kota bima. tetapi di

1 Undang-undang Republik Indonesia Nomor 1 tahun 1974 tentang Perkawinan dan Kompilasi Hukum Islam. 2014. Jakarta: Grahamedia Press

Sangaji Jurnal Pemikiran Syariah dan Hukum 
Indonesia masih banyak dijumpai kasus terjadinya pernikahan pada usia muda.

Fenomena pernikahan dini di kalangan remaja yang kompleks dengan prilaku pergaulan bebas atau karena perubahan pola pikir remaja yang berujung pada pernikahan dini yang dianggap sebagai jalan keluar dari sebuah kecelakan yang diakibatkan karena perilku pergaulan bebas remaja serta karena orangtua yang menginginkan anaknya menikah dalam usia dini dengan alasan karena masalah ekonomi, masalah sosial. observasi awal peneliti bahwa selama 3 tahun terakhir dari tahun 2017-2019 jumlah yang mengajukan dispensasi nikah yaitu 164 dengan rincian tahun 2017 sebanyak 68 orang, tahun 2018 sebanyak 76 orang dan tahun 2019 sebanyak 20 orang dari Januari sampai 06 Maret, artinya dari sekian tahun ada peningkatan begitupun dengan tahun 2019 dalam jangka waktu 2 bulan ${ }^{2}$

Berdasarkan data observasi awal diatas maka perlu dikaji dari aspek remaja dalam hal ini dengan mengetahui perspektif mahasiswa fakultas syariah dan fakultas tarbiyah tahun 2018 tentang pernikahan dini, melalui penilaian dan tangapan mahasiswa tentang pernikahan dini serta strategi dari para mahasiswa dalam merespon pernikahan dini yang terjadi di Kota

2 Data diperoleh dari Pengadilan Agama Bima dan diperkuat dari sumber (http://sipp.pa-bima.go.id). 
Bima. akan di bahas dan dianalisis secara seksama berdasarkan teori, keadaan lapangan, wawancara dan pengumpulan data kepada sejumlah responden yang berstatus sebagai mahasiswa kampus IAI Muhammadiyah Bima.

\section{PEMBAHASAN}

\section{A. Konsep Teori yang Relevan}

\section{Teori Efektivitas Hukum}

Teori Efektivitas Hukum merupakan teori yang mengkaji dan menganalisis tentang keberhasilan, kegagalan dan faktor-faktor yang mempengaruhi dalam pelaksanaan dan penerapan hukum.

\section{Pernikahan dini}

Pernikahan dini adalah perkawinan yang dilakukan di bawah usia yang disediakan serta disiapkan untuk dewasa yang diperbarui dan perbaikan rumah tangga ${ }^{3}$.yang dimaksud dalam hal ini adalah anak yang tidak sesuai batas perkawinan yaitu laki-laki harus berusia 19 tahun dan perempuan berusia 16 tahun, jika perkawinan terjadi di bawah usia batas yang telah menjadi peraturan maka

3 Nukman, 2009. Yang dimaksud dengan pernikahan dini. Yogyakarta : paradigma hal 32

Sangaji Jurnal Pemikiran Syariah dan Hukum 
perkawinan tersebut disebut sebagai perkawinan di bawah umur.

Dengan demikian usia perkawinan memiliki batasan, yaitu menurut perundangan secara yuridis formal bahwa dalam pasal 7 ayat (1) Undang-undang No.1 Tahun 1974 perkawinan hanya diizinkan jika pihak pria sudah mencapai umur 19 tahun dan pihak wanita sudah mencapai umur 16 tahun. Itu artinya, pria dan wanita yang usianya di bawah ketentuan tersebut belum boleh melaksanakan perkawinan. Jika kedua calon tidak memiliki orang tua lagi atau orang tua yang bersangkutan tidak mampu menyatakan kehendaknya, misalnya karena memiliki kemunduran ingatan, sakit jiwa, atau lainnya, maka izin yang dimaksud yang diperoleh dari wali, atau orang yang memelihara, atau keluarga yang mempunyai hubungan darah dengan kedua calon mempelai dalam garis ke atas selama mereka masih hidup dan mampu menyatakan kehendaknya.

Dalam hal seorang dari kedua orang tua meninggal dunia atau dalam keadaan tidak mampu menyatakan kehendaknya, maka izin yang dimaksud ayat (2) pasal 6 ini cukup diperoleh dari orang tua yang masih hidup atau dari orang tua yang mampu menyatakan kehendaknya. Maka 
izin diperoleh dari wali orang yang memelihara atau keluarga yang mempunyai hubungan darah dan garis keturunan lurus ke atas selama mereka masih hidup dan dalam keadaan mampu menyatakan kehendaknya (pasal 6 [3-4] Undang-undang Perkawinan Nomor 1 Tahun 1974).

Perundangan memberikan batas dalam perkawinan agar bisa menjaga kesehatan suami-istri dan keturunan, dengan demikian, peraturan usia ini sesungguhnya sesuai dengan prinsip perkawinan yang menyatakan bahwa calon suami dan istri harus telah matang jiwa dan raganya. Tujuannya agar perkawinan itu menciptakan keluarga yagn langgeng dan bahagia, serta memberikan keturunan yan sehat tanpa bberujung pada perceraian dan prematur. Selain itu juga jika perkawinan terjadi tidak sesuai dengan perundangan yaitu umur perkawinan tidak memenuhi syarat maka akan diberikan dispensasi sesuai dengan pasal 13 keputusan Menteri Agama Nomor 298 Tahun 2003 tentang pencatatan nikah bahwa "apabila seorang calon suami belum mencapai umur 19 tahun dan calon istri belum mencapai 16 tahun, harus mendapat dispensasi dari pengadilan".

Sangaji Jurnal Pemikiran Syariah dan Hukum 
Dalam artian misalnya karena pergaulan bebas yang permisif (kumpul kebo, hamil di luar nikah dan sebagainya), maka Undang-undang perkawinan No.1 tahun 1974 memberikan kemungkinan untuk menyimpang dari batas usia tersebut. Dalam keadaan darurat seperti itu, diperbolehkan untuk meminta dispensasi kepada pengadilan atau pejabat lain yang ditunjuk oleh kedua orang tua dari pihak pria maupun wanita.

\section{Implikasi Pernikahan Dini}

Pernikahan dini yang dilakukan tidak bisa dipungkiri setiap keputusan yang diambil akan memiliki konsekuensi hukum, secara suka ataupun tidak suka akan dialami oleh mereka yang melakukan hal tersebut antara lain :

a) Putus Sekolah

Hampir tidak bisa dipastikan pengantik anak adalah generasi putus sekolah dan bahkan yang tidak mengenyam pendidikan sama sekali, kesempatan mereka untuk mengenyam pendidikan yang lebih tinggi menjadi mimpi bahkan tidak sedikit pula yang tidak menyelesaikan bangku pendidikan dasar ${ }^{4}$.

b) Kekerasan dalam rumah tangga

${ }^{4}$ Gultom, Maidin. 2013. Perlindungan Hukum terhadap Anak dan Perempuan. Bandung: PT. Refika Aditama hlm 100 
Korban KDRT biasanya gadis muda yang dikawinkan di usia dini lazimnya bersuamikan pria yang berusia jauh lebih tua dari dirinya, akibat margin usia yang jauh inilah hamper muncul problem komunikasi keluarga, ekonomi maupun seksual diantara keduannya sehingga muncullah kekerasan dalam rumah tangga tersebut yang bisa menyakitkan pasangan dan yang menjadi korbannya adalah perempuan sebagai kaum rentan ${ }^{5}$.

c) Perceraian

Akibat tidak harmonisnya rumah tangga, maupun komunikasi yang tidak sejalan dengan kondisi rumah tangga perkawinan di bawah umur bisa berdampak pada terjadinya perceraian, hal ini tidak bisa dielakkan perempuan yang menjadi korban sulit dan bahkan tidak bisa melanjutkan sekolah bahkan malu untuk melanjutkan sekolah, status janda di usia muda pun menjadi identitas tersendiri. Perkawinan di bawah umur tidak jarang memunculkan banyak masalah yang sangat

5 Khaeron Sirin. 2009. Fikih Perkawinan dibawah Umur. Jakarta: Ghalia Indonesia hlm 33

Sangaji Jurnal Pemikiran Syariah dan Hukum 
pelik di dalam rumah tangga dan kerap berakhir dengan perceraian 6 .

Masih banyak dampak dari pernikahan dini jika ingin dieksplisitkan dengan rincian yang jelas akan tetapi yang paling krusial dan sering dialami yang berdampak sangat besar adalah ketiga poin di atas dan inferior perempuan atas subordinitas laki-lakilah jika implikasi dari pernikahan dini terjadi maka perempuan yang harus merasakan beban secara psikologis, moral, dan lain sebagainya.

\section{B. Kajian Penelitian Terdahulu}

Berdasarkan hasil penelusuran pustaka ternyata telah banyak penelitian yang membahas tentang masalah pernikahan dini, diantaranya adalah: Penelitian Akif Khilmiyah (2014), yang berjudul: "Pandangan Remaja dan Orang Tua Terhadap Pernikahan Dini dalam Membangun Keluarga di Kabupaten Bantul". Penelitian ini menggunakan metode penelitian deskriptif kualitatif. Penelitin ini menghasilkan: bahwa pernikahan dini lebih banyak dampak Jakarta : Diaksara.

Hlm 110 
negatifnya daripada manfaatnya. Oleh karena itu perlu dilakukan upaya penyuluhan tentang nikah dini kepada orang tua dan remaja yang bertujuan untuk melakukan pencegahan. Selain itu juga perlu dilakukan pendampingan kepada pelaku nikah dini, agar dapat menciptakan keluarga yang sejahtera lahir batin. Penelitian tersebut digunakan untuk memperkaya landasan teori.

Penelitian Mubasyaroh (2016), yang berjudul: "Analisis Faktor Penyebab Pernikahan Dini dan Dampaknya bagi Pelakunya". Penelitian ini menggunakan metode kualitatif deskriptif. Penelitian ini menghasilkan: Pernikahan dini pada remaja pada dasarnya berdampak pada segi fisik maupun biologis remaja, remaja yang hamil akan lebih mudah menderita anemia selagi hamil dan melahirkan, salah satu penyebab tingginya kematian ibu dan bayi. Kehilangan kesempatan mengecap pendidikan yang lebih tinggi. Disamping itu juga memiliki dampak psikologis bagi pelakunya. Penelitian tersebut digunakan untuk memperkaya landasan teori.

Penelitian Beteq Sardi (2014), berjudul : "Faktor-Faktor Pendorong Pernikahan Dini dan Dampaknya di Desa Mahak Baru Kecamatan Sungai Boh Kabupaten Malinau". Peneliti ini 
menggunakan metode deskriptif. Penelitian ini menghasilkan: faktor yang mendorong pernikahan dini adalah faktor ekonomi, faktor pendidikan, faktor orang tua, dan faktor adat istiadat. Dampaknya yang terjadi dalam pernikahan dini yaitu dampak negatif dan positif. Dampak positif, dapat membantu meringankan beban ekonomi orang tua, dan mencegah terjadinya perzinaan dikalangan remaja, dan dapat memberikan pengajaran pada anak untuk mempunyai rasa tanggung jawab dan belajar untuk memenuhi kebutuhan hidup sehari-hari. Dampak negatifsering adanya perselisihan yang berakibat terjadinya pertengkaran antara suami isteri dalam kehidupan berumah tangga sehari-harinya. Penelitian tersebut digunakan untuk memperkaya landasan teori.

Penelitian Agus Mahfudin dan Khoirotul Waqi'ah (2016), yang berjudul: "Pernikahan Dini dan Pengaruhnya terhadap Keluarga di Kabupaten Sumenep Jawa Timur". Penelitian ini menggunakan metode field risearch. Penelitian ini menghasilkan: Masalah yang dialami oleh pasangan perkawinan usia muda seperti adanya keegoisan antara pasangan itu sendiri, terjadinya pertengkaran, percekcokan, bentrokan antar suami-istri yang jika ini terus menerus dapat 
berdampak pada perceraian yang tidak melalui peradilan dikarenakan pernikahan mereka yang di bawah tangan atau sirri. Dan masalah yang timbul tidak hanya dirasakan oleh pasangan perkawinan usia muda tersebut tetapi juga berpengaruh terhadap orang tua kedua belah pihak karena apabila perkawinan diantara anak-anak mereka lancar maka kedua orang tua mereka akan merasa senang dan bahagia. Namun apabila kebalikannya perkawinan dari anak-anaknya mengalami kegagalan maka mereka akan merasa sedih dan kecewa akan keadaan rumah tangga anak-anaknya. Dari kegagalan perkawinan anak-anaknya tersebut tidak menutup kemungkinan silaturahmi diantara keluarga tersebut akan terputus. Penelitian tersebut digunakan untuk memperkaya landasan teori.

Penelitian Erni Dwi Widyana, Afnani Toyibah, Luh Putu Mega Esa Prani (2015), yang berjudul: "Pola Asuh Anak dan Pernikahan Usia Dini“. Penelitian ini menghasilkan kesimpulan ada perbedaan pola asuh anak antara pasangan usia dini dengan pasangan usia dewasa penuh di Wilayah Kerja Puskesmas Wagir Kabupaten Malang tahun 2013. Penelitian tersebut digunakan untuk memperkaya landasan teori.

Sangaji Jurnal Pemikiran Syariah dan Hukum 
Kelima penelitian di atas sudah membahas tentang Pernikahan Usia Dini dan Pola Asuh Pada Anak. Dari kelima penelitian di atas pernikahan dini disebabkan oleh faktor rendahnya tingkat pendidikan, ekonomi keluarga, dan dorongan orang tua. Pola asuh yang diterapkan antara orang tua yang menikah dini dengan orang tua yang sudah dewasa mempunyai perbedaan. Hal ini sudah dibuktikan oleh penelitian di atas. Kelima penelitian di atas belum membahas bagaimana penilaian mahasiswa institut agama islam muhammadiyah bima.

\section{METODE PENELITIAN}

\section{A. Jenis Penelitian}

Jenis Penelitian yang digunakan ialah Field research (penelitian lapangan), yang berupaya mencoba mendeskripsikan berdasarkan pendapat dan menganalisis fenomena sosial berupa pernikahan dini.

\section{B. Pendekatan Penelitian}

Pendekatan yang digunakan dalam penelitian ini adalah pendekatan yuridis empiris merupakan penelitian dengan tujuan utama memperoleh wawasan dari topik. 
pengumpulan data yang digunakan dalam penelitian ini adalah wawancara. Hal ini bertujuan untuk memperoleh pemahaman tentang alasan yang mendasari opini dan motivasi. Dalam hal ini adalah mengenai persoalan yang berkaitan dengan praktek perkawinan yang calon mempelai perempuannya atau laki-laki yang masih dikategorikan sebagai anak.

\section{Sumber Data}

Sumber data yang dimaksud dalam penelitian ini adalah subyek dari mana data yang diperoleh. Ada dua macam data yang dipergunakan yakni data primer dan data sekunder.

1. Data Primer

Data primer adalah data yang diperoleh langsung dari subyek atau obyek penelitian dengan mengenakan alat pengambilan data langsung pada subyek atau obyek sebagai sumber informasi yang dicari dan yang akan diteliti.

2. Data Sekunder

Data sekunder adalah data yang diperoleh dari pihak lain, tidak langsung diperoleh peneliti dari subyek penelitiannya, dan data ini terwujud data dokumentasi 
atau data laporan yang tersedia. Data ini berfungsi sumber data yang dijadikan sebagai data pelengkap dan pendukung dari data primer. Sedangkan data sekunder ini didapat dari beberapa sumber yang terkait informasi tentang penelitian ini, misalnya: dokumen, buku-buku atau lewat orang lain yang mengetahui data-data yang dibutuhkan seperti penghulu dan pembimbing pernikahan.

\section{Tehnik Pengumpulan Data}

Adapun tehnik pengumpulan data yang digunakan dalam penelitian ini adalah mengumpulkan data-data dari hasil penelitian lapangan melalui wawancara dan juga dari buku-buku, artikel dan lain-lainnya yang berkaitan dengan pernikahan dini.

\section{E. Tehnik Analisis Data}

Analisis data adalah proses pengorganisasian dan mengurutkan data ke dalam pola, kategori dan satuan uraian dasar sehingga dapat ditemukan tema dan dapat dirumuskan hipotesis kerja seperti yang disarankan oleh data (Moleong 1999 : 103). Penelitian ini berbentuk penelitian deskriptif kualitatif yaitu bentuk yang menuturkan dan menafsirkan data yang ada tentang situasi dan kondisi yang dialami. 
Analisis data dilakukan dengan tahapan, pengumpulan data, input data, kategorisasi dan penarikan kesimpulan.

Sangaji Jurnal Pemikiran Syariah dan Hukum 


\section{DAFTAR PUSTAKA}

Cholid Narbuko, Abu Achmadi, 2010, Metodologi Penelitian, Jakarta: PT. Bumi Sumadi Suryabrata, 1995, Metode Penelitian, Jakarta: Raja Grafindo Persada, Aksara, Cet.II, Syaifuddin Azwar, 1998, Metode Penelitian, Yogyakarta: Pustaka Pelajar Offset,

Rusmini. 2015. Dampak menikah dini dikalangan perempuan di desa batulappa kecematan batulappa kabupaten pinrang. Jurusan sosiologo. Fakultas ilmu sosial dan ilmu politik. Universitas hasanuddin makassar.

Eka Narwanti, Umiiroh,2014. Pengaruh Kesiapan Psikologis. Fakultas Ilmu Kesehatan. Universitas muhammadiyah purwokerto.

Cunengsih. 2013. Kajian Perkawinan Usia dini. Fakultas keguruan dan ilmu pendidikan. Universitas muhammadiyah purwokerto.

Ibadurrahman . 2015. Perkawinan usia dini dalam prespektif undang undang perlindungan anak (studi kasus di kua kecamatan kaliwungu kab. Kendal). Jurusan akhwal al syahsiyah. Fakultas syari'ah. Universitas islam negeri walisongo semarang. 